\title{
OKLAHOMA OIL AND NATURAL GAS SEVERANCE TAXES: A COMPARATIVE ANALYSIS
}

\author{
Mary N. Gade \\ Oklahoma State University • Stillwater, OK \\ Karen Maguire \\ Oklahoma State University • Stillwater, OK \\ Francis Makamu \\ Oklahoma State University • Stillwater, OK
}

\section{ABSTRACT}

Oklahoma assesses a production tax of seven percent on the extraction of oil, natural gas, and other minerals. However, since July 2002, it has taxed production from horizontal wells at one percent for the first 48 months of production. This is a significant tax incentive relative to the neighboring state of Texas, particularly considering the limited evidence of the effectiveness of severance tax incentives for increasing in-state development of immobile resources. This paper examines whether the tax incentive encouraged horizontal development in Oklahoma relative to Texas. Our findings indicate that the incentive is not associated with an increase in development.

Keywords: Severance Tax, Oil and Natural Gas, Hydraulic Fracturing JEL Codes: H71, H73, Q32, Q35, Q48

\section{INTRODUCTION}

The development of horizontal drilling and hydraulic fracturing technologies has triggered a resurgence in oil and natural gas production in the United States. State governments levy different types of production taxes on these unconventional wells, at different rates, with a diverse mix of exemptions, deductions, and incentives. These tax policies are designed to encourage industry activity, development, job creation, and to enhance economic benefits to the state.

The state of Oklahoma has carried one of the lowest effective tax rates on horizontal wells when compared to peer states. ${ }^{1}$ The low rate is partly triggered by a

\footnotetext{
${ }^{1}$ Throughout the paper, references to horizontal drilling and horizontal wells, refer to those wells that use a combination of horizontal drilling and hydraulically fracturing to access unconventional oil and natural gas resources. These are commonly referred to as fracked or hydraulically fractured wells. See Fitzgerald (2012) for a detailed discussion of the economics of fracking.
} 
four-year production tax holiday that reduces the tax on newly completed horizontal wells from seven to one percent in the first 48 months of production. This tax break has a significant impact on state revenues, but its effect on drilling activity is an open question. This paper empirically examines whether the horizontal wells severance tax incentive has encouraged horizontal drilling activity in Oklahoma relative to Texas.

For the second straight year, Oklahomans are faced with nearly a \$1-billiondollar budget shortfall (KFOR 2017; NewsOn6 2015). According to the Oklahoma Policy Institute, the proposed budget is 15.6 percent below the fiscal year 2009 budget and 39 out of 73 agencies that are allocated state budget funds have been cut by 20 percent or more since then (OK Policy 2017). The state's budget issues have been blamed on a number of factors, including drops in the corporate income tax, an increase in the cost of various tax incentives, and falling oil prices (OK Policy 2017; Wertz 2016). Specifically, the Oklahoma Policy Institute argues that "tax incentives have more than doubled between 2010 and 2014" and that the largest of these incentives are from "lower tax rates on oil and gas production" (OK Policy 2017).

Previous theoretical literature on oil and gas taxes by Haughton and Tuerck (2006), modeled a proposed indirect processing tax in Louisiana on oil and gas produced in the Outer Continental Shelf (OCS) and determined that there would be short term gains in state tax revenue, but they were not sustained over the long term. Previous empirical literature has examined the effects of the state's political environment on oil and gas development and found that price rather than politics determined oil and gas development (Maguire 2012). Although, on federal lands, the regulatory environment was a key factor in the amount of oil and gas leasing (Maguire 2016). ${ }^{2}$ Other work has examined the effects of oil and gas development on regional economic outcomes such as unemployment with mixed results (Lee 2015; Munasib \& Rickman 2015; Weinstein 2014; Weber, 2014; Weber 2012; Michaels, 2010).

To our knowledge, our study is the first to examine the effects of Oklahoma's horizontal well tax incentives. The subject is of interest as Oklahoma offers a generous exemption on horizontal production while other neighboring states, such as Texas, do not. Providing tax incentives would be considered an effective policy for the state if it stimulates development. However, the alternative would suggest that additional production is profitable to firms regardless of the incentives and

\footnotetext{
${ }^{2}$ Oklahoma and Texas do not have significant federal lands. (BLM, Public Land Statistics)
} 
extending tax breaks only harms Oklahoma's economy by reducing its tax revenue.

The contemporary Tiebout (1956) tax competition literature devotes much attention to the question of whether or not state tax differentials have an empirical impact on the location of economic activity. Theoretically, when a jurisdiction lowers its tax rate on a mobile capital base, the net of tax return rises above that available elsewhere, and capital flows in until net of tax returns are equalized across all jurisdictions. The resulting incentive is that a lower tax rate on capital relative to surrounding jurisdictions has the potential to encourage economic activity as part of state development policy. Thus, states utilize exemptions, deductions, and other tax incentives in an effort to stimulate economic development.

Most of the empirical work on state tax incentives centers on the effects of state taxation on geographically mobile capital with mixed results. Evidence ranges from a positive influence of incentives on location (Bartik 1985; Helms 1985; Bartik 1989; Papke 1991; Papke 1994; Holmes, 1998; Strauss-Kahn \& Vives, 2009) to a small effect or none at all (Schmenner 1982; Plaut \& Pluta 1983; Carlton 1983; Schmenner, Huber \& Cook 1987; Blair \& Premus 1987; Dabney 1991; Tannenwald 1996; Lee 2008). Literature reviews also suggest that the results are somewhat ambiguous (Wasylenko 1999; Buss 2001; and Arauzo-Carod, Liviano-Solis, \& Manjón-Antolín, 2010).

Examination of the effects of state severance tax incentives on oil and gas drilling and production activity requires an alternative perspective. Nonrenewable natural resources are geographically immobile. Firms engaged in oil and gas production cannot change location to the extent that their main capital consists of the immobile reserve base. Therefore, state severance tax preferences cannot encourage relocation across jurisdictions. Firms can respond, however, by altering the level and timing of extraction as state tax policy changes.

The introduction of horizontal drilling along with hydraulic fracturing technology has expanded the ability of firms to profitably recover natural gas and oil from unconventional sources (EIA 2011). However, horizontal drilling comes with higher costs relative to conventional drilling. A horizontal well can cost between 25 to 300 percent more to drill and complete. Due to the difference in cost structure, horizontal drilling is restricted to geological plays with low permeability where conventional wells would not be considered economically viable (Helms, 2008).

There have been few empirical studies that look at how firms in nonrenewable resource industries respond to state tax incentives. They have included simulation and/or econometric studies of the relationship between a specific tax policy and natural resource exploration and production. For example, Kunce, Gerking, and 
Maddux, (2003) simulate the effects of state tax policy changes in Wyoming on both the level and timing of exploration and output in the state. The simulation is based on the standard model of natural resource supply from Pindyck (1978) and estimates exploration costs, production of reserve additions, and extraction costs for Wyoming while incorporating the specific tax parameters that are of interest to the industry. In contrast, Leighty and Lin (2012) estimate field-specific cost functions based on cost and production data from Alaska's North Slope and use those estimated equations to model production decisions and simulate the impact of tax policy on the production rate. Lastly, Black, McCoy, and Weber (2016), find that taxes on the impacts of drilling in Pennsylvania, which could act as a deterrent to oil and gas development, have instead not led to significant declines. The conclusions drawn from these studies and others suggest that the volume of oil and natural gas production and drilling activity is insensitive to severance tax rate changes (see also Helmski-Oskou, Narayanan, Glover, Lyon, \& Sinha 1992; Kunce, 2003; Chakravorty, Gerking, \& Leach, 2010; Kaiser 2012).

In this paper, we build on this existing literature by examining whether Oklahoma's severance tax reduction has led to disparate effects for horizontal versus conventional drilling as compared with Texas. Our findings suggest that the Oklahoma tax exemption has not significantly increased horizontal drilling activity.

\section{BACKGROUND}

\section{Oil and Natural Gas Resources}

Oklahoma and Texas are not only among the states to apply the lowest oil and gas production taxes in the nation, but are also among the major contributors of oil and gas in the country. The states are selected in this study for their regional proximity as well as their long history of oil and gas production. For the period 1982 to 2013, Texas had the highest production (onshore) of natural gas and Oklahoma comes in third position (EIA 2015). The Hugoton gas field which contains one of the largest producing natural gas fields in the U.S. is located in southwestern Kansas, but includes parts of the Texas and Oklahoma panhandles. In 2013, Texas accounted for 29 percent of the country's marketed gas production, well above any other state. Oklahoma accounted for 7.1 percent of the U.S. natural gas production and 8.4 percent of the U.S. marketed production in 2013. Oklahoma is one of the leading states in terms of the number of gas wells drilled, only behind Ohio, Pennsylvania, West Virginia and Texas. Texas is also the leading oil producing state with production 
levels sometimes exceeding the federal offshore areas. Oklahoma ranked fifth in crude oil production in the nation in 2014 (EIA 2016).

\section{Horizontal drilling and Hydraulic fracturing}

Horizontal drilling combined with hydraulic fracturing technology allows producers to develop deposits of oil and natural gas that are trapped in deep shale and tight sands formations often one mile below the surface (API 2009). The concept of hydraulic fracturing was developed in 1891, and implemented for the first time in Texas around 1929, but it only become commercially viable in the 1980s. The cost of horizontal drilling is generally higher than the conventional vertical drilling, up to 300 percent. However, when financially viable a horizontal drill can produce 2.5 to 7 times the rate and reserves of conventional wells and allow producers to access once economically infeasible resources (King, 1993). For approximately 10 years beginning in the early 2000 s, the price of oil and natural gas was rising making more expensive and complicated methods like hydraulic fracturing more attractive. ${ }^{3}$ It should be noted that gas prices have declined since 2008 and oil prices have fallen significantly recently, leading to a reduction in oil and gas development activity, but this decline occurred largely after our sample period, which ends in 2013 (Arezki \& Blanchard, 2014; Asche, Oglend \& Osmundsen, 2012; Baffes, Kose, \& Stocker, 2015).

\section{State Severance Tax Structures: Oklahoma, Texas}

Tax structures are not easy to compare as they vary across states and at different levels of government authority, i.e. federal, state, and local jurisdictions. To address this problem, the literature often makes use of the effective tax rates, taxes divided by production value, in order to account for various form of tax incentives granted by states. For example, including severance, property, income and sale taxes, Oklahoma and Texas have in FY 2010-2011 effective tax rates between 7.4 and 8.4 percent (Carey 2014). Although their effective tax rates are similar, there are major differences in their tax structures. For example, Texas does not levy a corporate income tax while Oklahoma does. In addition, counties can impose property taxes on drilling companies, which are independent of the well's economic value, but the revenue from taxation on structures and equipment are generally not as large as the revenue obtained from the severance tax (Kunce \& Morgan, 2005). Also, state and

\footnotetext{
${ }^{3}$ U.S. Energy Information Administration. 2015. U.S Natural Gas Prices. Wellhead price from 1922 to 2012.
} 
federal corporate income taxes are levied on the firm profit and have very little effect on the firm's decision to explore and produce. They are more likely to affect future drilling investments and output, rather than the actual number of drilling permits issued (Deacon, 1993).

States grant numerous exemptions and credits to oil and gas producers (Kunce, 2003). For example, Oklahoma and Texas offer exemptions for inactive wells for at least a certain period after the date of certification of two or three years of inactivity. Their tax structures also differ on other features. The Oklahoma gross severance tax rate on gas is 7 percent when the price of gas exceeds $\$ 2.10$ per thousand cubic feet (Mcf). The state offers exemptions on severance tax for recovery projects, inactive wells (reestablished production), horizontally drilled wells, new discovery wells, and seismic exploration. Since 2002, Oklahoma has exempted gas production from horizontal drilling to claim only 1 percent for the first four years of production. ${ }^{4}$ It is the most generous exemption provided by the state which can be claimed by drilling companies for unlimited production for the first forty-eight months regardless of the current market price.

Like Oklahoma, Texas has taxed oil and gas production at a rate of 7.5 percent of the market value of gas produced and 4.6 percent of the market value of oil produced. ${ }^{5}$ (See Appendix: Table A2 for detailed information on state tax incentives for Oklahoma and Texas.) The state has provided natural gas tax incentives since 1989 in the form of an exemption for production of gas with higher drilling costs ("high cost gas") and inactive wells, both for a period of ten years. The tax benefits have been extended several times and made permanent in 2003. More important to our identification, the tax code does not include production tax exemptions for horizontally drilled wells in oil and gas production. ${ }^{6}$

Overall, and essential to our identification strategy, unlike Oklahoma, Texas does not provide tax incentives that specifically target horizontal drilling. Also, Texas has not enacted a major change in their tax code for other types of production. Texas has not revised chapter 201, its administrative code on tax exemption for natural gas, since 1997, except for minor modifications in 2005 and 2009 (House Bill 2161 and Senate Bill 997). There was also a myriad of minor regulatory changes, but no major statewide regulatory changes over the period (OCC 2016, RRC 2016). The empirical specification will control for static differences in the regulatory and tax structure

\footnotetext{
${ }^{4}$ Oklahoma Statutes. Chapter $68 \S 1001(\mathrm{E})$.

${ }^{5}$ Texas Tax Code. Chapter 201 section 52 (A).

${ }^{6}$ Other exemptions comprise gas production from low producing wells on and after 2005 and gas production in association with geothermal energy production after 2009.
} 
between Texas and Oklahoma, but does not control for dynamic regulatory or tax changes occurring over the sample period in either Texas or Oklahoma. However, our research, indicates that there have not been major relevant regulatory or tax policy changes over the sample.

While it is clear that increases in oil and gas production lead to increases in tax revenue, it is not clear that the reduction in Oklahoma's severance tax rate for horizontal wells will lead to additional oil and gas development. This paper focuses on the empirical question of whether the tax credit on horizontal drilling in Oklahoma is associated with an increase in drilling permits relative to Texas.

\section{DATA}

For our analysis, the number of oil and natural gas permits issued serves as our measure of oil and gas development. The steps in the development process include permitting, drilling, completion, and production. In each step after the initial drilling permit is issued, firms face additional costs and resource constraints in order to complete the well development process. For this reason, the number of permits issued provides the best measure of the influence of a tax policy on a firm's initial oil and gas development decision without the confounding effects of subsequent changes in development costs and other constraints facing these firms. The permit provides the firm with authorization to drill in the designated location abiding by any state restrictions regarding drilling methods. ${ }^{7}$ Therefore, the measure provides a complete set of oil and gas development activity; for each oil or natural gas well drilled in a state, the state's oil and gas commission requires a permit.

The drilling permit data for the analysis were collected from the relevant state oil and gas and or geologic agency; The Oil and Gas Division of The Oklahoma Corporation Commission and The Railroad Commission of Texas. ${ }^{8}$ Each drilling permit is categorized by the relevant agency as conventional or horizontal. In addition, permits are designated as oil, natural gas, or simply oil and gas. ${ }^{9}$ Data are collected for the sample period 1995-2013 and aggregated to the month-county level for each county during the sample period. In addition to permit data, we

\footnotetext{
${ }^{7}$ The permits typically require that drilling begin within 6 months to a year from the issue date and expire if not used. The number of permits issued and the number applied for are essentially the same. For example, in Oklahoma over the sample period only 20 permits were rejected. In order to eliminate those few cases where permits were denied, we used only approved permits in the measure.

${ }^{8}$ Permits for oil and gas drilling and recompletion were considered. Permits for other wells such as injection wells are excluded from the analysis. For Texas, only onshore permits are analyzed.

${ }^{9}$ For permits for oil and gas drilling that were not categorized separately as oil or natural gas, we defaulted to a joint oil and gas category.
} 
also collected data on monthly oil and natural gas prices by state from the Energy Information Association (EIA). ${ }^{10}$ Data on population and personal income at the county-year level were collected from the Bureau of Economic Analysis (BEA). Lastly, information on whether a county is a metro or non-metro and whether the counties were consistent oil and gas producing counties were collected from the Economic Research Service of the United States Department of Agriculture (ERSUSDA).

\section{EMPIRICAL SPECIFICATION}

The paper empirically examines whether the severance tax reduction in Oklahoma in 2002 is associated with an increase in the amount of horizontal drilling relative to Texas. The empirical analysis measures the influence of the horizontal drilling severance tax policy in Oklahoma on the number of drilling permits issued. By using a difference in difference approach we can examine whether Oklahoma's state policy is associated with differences in the number of horizontal and conventional drilling permits issued in Oklahoma as compared with Texas.

The main specification of the fixed effects model is:

$Y_{i t}=\propto+\beta_{1} R_{j} T_{y}+\beta_{2}$ Price $_{j t}+\beta_{3}$ Inc $_{i y}+\beta_{4}$ Pop $_{i y}+\beta_{5} i+\beta_{6} y+\beta_{7} t+\varepsilon_{i t}$

Where $i=$ county, $j=$ state, $t=$ month, and $y=$ year

$(Y)$ represents the county-month number of permits issued. $(R)$ is an indicator of the Oklahoma tax policy of interest. $(T)$ is the time period when the Oklahoma tax policy is in effect. (Price) is a state-month real oil or natural gas price. ${ }^{11}$ (Inc) is county-year real personal income. Lastly, (Pop) is the county-year population.

The difference-in-difference (DID) technique that is used relies on the assumption that changes in drilling permits over time would have been the same in both the treatment, Oklahoma, and control state, Texas, in the absence of the intervention. Figure 1, shows that from 1995 through the early 2000s, the share of conventional and horizontal drilling permits approved was constant for both

\footnotetext{
${ }^{10}$ For oil prices, we used the EIA first purchase price, while for natural gas prices we used the EIA citygate price; first purchase or wellhead prices for natural gas were discontinued in 2013.

${ }^{11}$ The policy change in Oklahoma was implemented in large part to promote the implementation of hydraulic fracturing technology and increase oil and gas development in Oklahoma. While oil and natural gas prices vary by state, they are highly correlated across states and Texas did not adopt the same tax policy. Technology, which is clearly correlated with price, was the main factor in Oklahoma's decision, though some correlation between the policy and price cannot be ruled out.
} 
states. This is due largely to the absence of hydraulic fracturing technology prior to the mid-2000s and its rapid adoption throughout the United States thereafter. The extent to which the rise in horizontal drilling in Oklahoma demonstrated in Figure 1 is due to this technological advancement and the degree to which it was influenced by the tax policy in Oklahoma is therefore an empirical question. By differencing out the availability of hydraulic fracturing technology, which was also available in Texas we are focused on identifying the Oklahoma tax policy impacts. Specifically, the county and month fixed effects specification controls for all time invariant county characteristics, and the effects of seasonal and annual national economic and policy changes that influenced both Oklahoma and Texas. Still, the possibility of endogeneity exists due to unmeasured county-level heterogeneity in resource potential, which may lead to changes in the number of permits issued and the implementation of the tax policy. In order to control for resource availability, we have used an alternative sample to focus on geologically similar regions across states as designated by the United States Geologic Survey (USGS). ${ }^{12}$ In addition, to address concerns over unmeasured local economic factors, we have controlled for dynamic changes in personal income and population. Results for the full sample are provided below.

\section{RESULTS}

The findings in Table 1 indicate that there is not a robust statistically significant relationship between the implementation of the Oklahoma tax policy in 2002 and the number of horizontal permits issued. Despite the dramatic increase in horizontal drilling demonstrated in Figure 2, the results suggest that the tax break was not a determining factor, rather it was oil prices that had a significant influence. ${ }^{13}$ The rise in horizontal drilling was not limited to Oklahoma. Figure 2 also shows marked growth in the number of horizontal drilling permits in Texas, which did not have the policy. Clearly, the technological expansion of horizontal drilling crossed state lines and led to growth in permitting in both Texas and Oklahoma.

Oil prices have the expected finding, an increase in oil price is associated with an increase in both horizontal and conventional drilling permits. The coefficient of

\footnotetext{
${ }^{12}$ The data used in the empirical specification do not allow us to entirely control for differences in the amount of increase in oil and natural gas resource by county. While the regions are designated as geologically similar by the USGS, the USGS does not indicate the entire region has the same level of oil and natural gas resources. Using an alternative data set or empirical technique that controls for resource heterogeneity at the well level is left for future work.

${ }^{13}$ In addition, natural gas prices were also considered and the statistical and economic significance of the policy intervention were consistent when the analyses were conducted using natural gas rather than oil prices. Results available upon request.
} 
0.0038 on Oil Price in Table 1A column 1 combined with the standard deviation for Oil Price of 28.16 suggests that a one standard deviation increase in oil prices increases county month horizontal permits issued by 0.11 . This is an economically significant relationship given that the mean number of horizontal permits issued over the sample period is 1.06 . The finding for conventional permits is also statistically significant. The results in Table 1B, column 1 indicate that a one standard deviation increase in oil prices is associated with a 0.65 increase in the county-month conventional permits issued. This is also an economically significant finding given that the mean number of conventional drilling permits issued is 3.73 .

The findings for both horizontal and conventional permits indicate that there is not a consistently significant relationship between either horizontal or conventional drilling and the implementation of Oklahoma's tax policy. Robustness checks for the main sample are examined below.

\section{Oil and Gas Resource Availability}

There are several distinct geologic areas throughout the sample area. The USGS Central Region Energy Team assessed the oil and gas resources of the United States and developed geologic boundaries for the Oil and Gas Resource Assessment Project from 2005 through 2012. Each region, called a province, is defined by major geologic changes. ${ }^{14}$ (See Figure 3) The amount of oil and natural gas resource available is a key factor in determining the amount of drilling that will take place. Figure 4 shows that Texas has more oil and gas resources than Oklahoma and a larger increase in resources over the sample period..$^{15}$ The heterogeneity in resource availability may confound the effects of the tax policy, i.e. differences in the state's resource availability may lead to differential development behavior by firms independent of the tax policy. In order to control for resource availability, we analyzed a sample of counties which are in geologic regions that overlap the boundaries of the states. ${ }^{16}$ The assumption underlying this analysis is that counties in the same geologic region would be expected to have the same development potential before and after 2002, but for the change in Oklahoma's tax policy.

The findings for horizontal permitting remain consistent with the full sample

\footnotetext{
${ }^{14}$ See http://energy.usgs.gov/OilGas/AssessmentsData/NationalOilGasAssessment.aspx\#.VW3Pcc-6dpj, http://certmapper. cr.usgs.gov/data/noga00/natl/spatial/geodatabase/usprov12gdb.zip

${ }^{15}$ Proved reserves can increase due to an increase in resource price, technological growth, or through an expansion in oil and gas drilling activity (EIA 2017).

${ }^{16}$ The provinces that are included in the overlapping regions sample are the Anadarko Basin and the Bend Arch-Fort Worth Basin.
} 
if the analysis is completed for the overlapping geologic regions sample. Table 1, column 2 indicates that the policy is not statistically significantly associated with a change in horizontal permitting. Still, there may be differences in the amount of increase in oil or gas resources between Texas and Oklahoma counties in the overlapping regions sample due to differential changes in proved reserves. Our analysis does not control for these differences, but does provide a robustness check for the previous results using a more homogeneous resource area. The finding for conventional permitting becomes insignificant and changes sign, indicating that the negative coefficient found in the main sample may have been due to the heterogeneity in resource availability in the full sample. In this sample, there is not a statistically significant effect from the policy.

\section{Share of Permits}

Figure 2 shows that Texas has issued considerably more permits than Oklahoma. In order to determine if the findings are driven by variation in the magnitude of the number of permits issued, we have also analyzed the share of conventional and horizontal permits. Table 1, columns 3 show that for the alternative dependent variable, share of permits, the results for horizontal permitting become significant while conventional drilling remains insignificant. Specifically, the findings in Table 1A indicate that after the implementation of the tax policy, horizontal permitting increased. Importantly, however, the positive significant findings regarding horizontal permitting are limited to the construction of this alternative dependent variable and are not robust across specifications.

\section{Permits - Oil and Gas}

The findings thus far have distinguished permits by type, horizontal or conventional permit, but not by fuel, oil or natural gas. In order to determine if the tax policy was differentially affecting oil and gas permits, we examined the number of permits issued for wells other than oil wells. Oil and gas permits are often issued for oil and gas wells jointly, rather than specifically designating either oil or gas individually. In addition, many wells produce oil and natural gas with the ratio of oil and natural gas produced used to determine whether the well is designated oil or natural gas in a particular year. In order to analyze the permits separately, we constructed a variable that is a measure of the total number of county-month permits minus those that were designated as oil permits. The findings in Table 1A, column 4 indicate that the results for horizontal permits are insignificant. The policy did have a 
negative and statistically significant relationship with conventional permitting in this sample, but once again the magnitude and direction of influence are not consistent across specifications for the conventional permits.

\section{Resource Rich Counties}

Previously, we restricted the sample to overlapping geologic regions in order to analyze a more homogeneous sample in terms of the oil and gas resource availability. For this analysis, we focus on resource rich counties defined as those with continuous oil and/or gas production as reported by ERS-USDA. ${ }^{18}$ This specification highlights the potential differences in the relationship between the policy and counties that had marginal resource development versus counties that had continuous resource development. The analysis focuses on a more homogeneous sample in terms of resource development. The findings in Table $1 \mathrm{~A}$, column 5 indicate that horizontal permitting declined in this sample full sample, the coefficient on the policy variable was -1.18 , but for resource rich counties the decline was less -0.218 . The results are not consistent with the previous results, and do not support the hypothesis that Oklahoma's tax policy increased horizontal drilling. The policy influence on conventional permitting is also negative, but there is no differential relationship between the policy in marginal and resource rich counties. The lack of a consistent magnitude and direction for the tax policy on horizontal or conventional drilling indicate that there was not a robust statistically significant finding.

\section{CONCLUSION AND DISCUSSION}

Oklahoma's severance tax reduction was designed to promote the adoption of what was at the time a technological advancement in drilling. Resource rich states, such as Oklahoma rely on tax revenue from energy production in order to meet their fiscal obligations. This reliance has proven particularly salient recently as Oklahoma faces a budget shortfall. According to the Oklahoma Policy Institute, this shortfall is due not only to declining oil and gas production due to falling prices, but to tax incentives, both income and the severance tax reduction (OK Policy 2016, 2017). Prior to the current environment of declining energy prices, the boom in oil and gas drilling that followed the adoption of hydraulic fracturing technology was credited with providing jobs and revenue for state and local governments. The state tax implications of increased oil and gas production seem clear, but the benefits of

\footnotetext{
${ }^{18}$ See http://www.ers.usda.gov/data-products/county-level-oil-and-gas-production-in-the-us.aspx. The data on oil and gas production cover the period 2000-2011.
} 
the tax break can only be realized if the industry responds by ramping up production when the policy is implemented. Industry leaders, including the three largest oil companies in Oklahoma indicated that they would reduce drilling if the horizontal tax reduction was allowed to lapse, resulting in a production tax increase back to the full seven percent from the reduced one percent (Veith, 2014). The results in this paper suggest, however, that the rise in hydraulic fracturing was due to resource prices, rather than a response from oil and gas producers to the tax policy. In the case of Oklahoma's policy, our findings indicate that the policy is not associated with an increase in horizontal drilling.

Although no significant effect was found, it is not possible to entirely control for differences in the regulatory and resource environment in Texas and Oklahoma over the sample period using the current specifications. In terms of the potential for omitted variable bias due to differences in the regulatory environment, we have addressed this by examining the relevant policy environment, presented in Appendix A2, and have not found another significant relevant state-level regulatory change during the sample period. In order to address concerns over differences in the growth in resource endowments between Oklahoma and Texas we have examined the more homogeneous overlapping regions sample and have used the share of permits rather than the absolute number of permits as the dependent variable. Across the specifications, the results indicate that there is not a consistent statistically significant association between the Oklahoma tax policy and oil and gas development. Previous empirical work examining the effect of state tax incentives on geographically mobile capital has found mixed results and this work contributes to that literature; indicating that state tax credits may not provide incentives to increase production for an immobile resource such as oil and natural gas. However, the results also indicate that additional work on the benefits of state tax credits for immobile oil and gas resources is needed in order to determine whether these tax credits are having the desired outcome of increasing oil and gas development.

\section{REFERENCES}

API (2009). Hydraulic fracturing operations, well construction and integrity guidelines. American Petroleum Institute. API Guidance document HF1. http:// www.shalegas.energy.gov/resources/HF1.pdf, accessed September, 092015.

Arauzo-Carod, J. M., Liviano-Solis, D., \& Manjón-Antolín, M. (2010). Empirical studies in industrial location: an assessment of their methods and results. Journal of Regional Science, 50(3), 685-711. 
Arezki, R., \& Blanchard, O. (2014). Seven Questions About the Recent Oil Price Slump. IMFdirect - The IMF Blog, December 22, 2015.

Asche, F., Oglend, A., \& Osmundsen, P. (2012). Gas versus oil prices the impact of shale gas. Energy Policy (47), 117-124.

Baffes, J., Kose, A. O., \& Stocker, M. (April 2015). The great plunge in oil prices: causes, consequences, and policy responses. Working paper series. Koc Universtiy-Tusiad Economic Research Forum, 1-60.

Bartik, T. J. (1985). Business location decisions in the United States: Estimates of the effects of unionization, taxes, and other characteristics of states. Journal of Business \& Economic Statistics, 3(1), 14-22.

Bartik, T. J. (1989). Small business start-ups in the United States: Estimates of the effects of characteristics of states. Southern Economic Journal, 1004-1018.

Black, K. J., McCoy, S., \& Weber, J. G. (2016). When Externalities are taxed: The Effects and Incidence of Pennsylvania's Impact Fee on Shale Gas Wells. USAEE Working Paper, No. 16-272.

Blair, J. P., \& Premus, R. (1987). Major factors in industrial location: A review. Economic Development Quarterly, 1(1), 72-85.

Buss, T. F. (2001). The effect of state tax incentives on economic growth and firm location decisions: An overview of the literature. Economic Development Quarterly, 15(1), 90-105.

Carey, M. (2014). Effective severance tax rates [Memorandum], May 11, 2014. Colorado Legislative Council. Denver, CO.

Carlton, D. W. (1983). The location and employment choices of new firms: an econometric model with discrete and continuous endogenous variables. The Review of Economics and Statistics, 440-449.

Chakravorty, U., Gerking, S., \& Leach, A. (2010). State Tax Policy and Oil Production. U.S. Energy Tax Policy, 759-774.

Dabney, D. Y. (1991). Do enterprise zone incentives affect business location decisions? Economic Development Quarterly, 5(4), 325-334.

Deacon, R., (1993). Taxation, depletion, and welfare: A simulation study of the U.S. petroleum resource. Journal of Environmental Economics and Management, Volume 24, pp. 159-187.

EIA (2011). Review of emerging resources: U.S. shale gas and shale oil plays, Energy Information Administration, DOE. http://www.eia.gov/analysis/studies/ usshalegas/pdf/usshaleplays.pdf. Accessed August, 052015. 
EIA (2015). U.S. Energy Information Administration. Natural gas gross withdrawals and production. Authors' calculations. http://www.eia.gov/dnav/ng/ng_prod_ sum_a_epg0_fpd_mmcf_a.htm

EIA (2016). Energy Information Administration. U.S. States: State Profiles and Energy Estimates. https://www.eia.gov/state/ accessed (10/10/16)

EIA (2017). Energy Information Administration. Natural Gas: Definitions, Sources, and Explanatory Notes. (https://www.eia.gov/dnav/ng/TblDefs/ng_enr_ngl_ tbldef2.asp) accessed (11/1/17)

Fitzgerald, T. (2012). Frackonomics: some economics of hydraulic fracturing. Case W. Res. L. Rev., 63, 1337.

Haughton, J., \& Tuerck, D. (2006). The Incidence of State Taxes on Oil and Gas. Public Finance Review, 34(5), 527-550.

Headwaters Economics. (2013). Unconventional Oil and Natural Gas Production Tax rates: How does Oklahoma Compare to Peers? Bozeman, MT.

Helms, L.D. (2008). Horizontal Drilling. North Dakota Department of Mineral Resources Newsletter, 35(1), pp. 1-3.

Helms, L. J. (1985). The Effect of State and Local Taxes on Economic Growth: A Time Series--Cross Section Approach. The Review of Economics and Statistics, 574-582.

Helmi-Oskoui, B., Narayanan, R., Glover, T., Lyon, K. S., \& Sinha, M. (1992). Optimal extraction of petroleum resources: An empirical approach. Resources and energy, 14(3), 267-285.

Holmes, T. J. (1998). The effect of state policies on the location of manufacturing: Evidence from state borders. Journal of Political Economy, 106 (4), 667-705.

Kaiser, M. J. (2012). Modeling the horizontal well severance tax exemption in Louisiana. Energy, 40(1), 410-427.

KFOR. (2017). Oklahoma faces $\$ 878$ million shortfall for upcoming year, revenue failure declared. KFOR News Channel 4. http://kfor.com/2017/02/21/oklahomafaces-878-million-shortfall-for-upcoming-year-revenue-failure-declared/, accessed March 10, 2017.

King, R. F. (1993). Drilling sideways: A review of horizontal well technology and its domestic application. DOE/EIA/TR-0565. Washington, D.C.: Energy Information Administration.

Kunce, M. (2003). Effectiveness of severance tax incentives in the US oil industry. International Tax and Public Finance, 10(5), 565-587. 
Kunce, M., Gerking, S., Morgan, W., \& Maddux, R. (2003). State taxation, exploration, and production in the U.S. oil industry. Journal of Regional Science, 43 (4), 749-770.

Kunce, M., \& Morgan, W. E. (2005). Taxation of Oil and Gas in the United States 1970-1997. Nat. Resources J., 45, 77.

Lee, J. (2015). The regional economic impact of oil and gas extraction in Texas. Energy Policy, 87, 60-71

Lee, Y. (2008). Geographic redistribution of U.S. manufacturing and the role of state development policy. Journal of Urban Economics, 64(2), 436-450.

Leighty, W., \& Lin, C. Y. C. (2012). Tax policy can change the production path: A model of optimal oil extraction in Alaska. Energy Policy, 41, 759-774.

Maguire, Karen. (2012). Prices or Politics? The Influence of Markets and Political Party Changes on Oil and Gas Development in the United States, Energy Economics 34:2013-2020.

Maguire, Karen. (2016). Drill baby drill? Political influence on federal onshore oil and gas leasing in the Western United States. Economics of Governance, 17 (2), 131-164.

Michaels, Guy (2010). The Long Term Consequences of Resource-Based Specialisation. The Economic Journal. 121, 31-57.

Munasib, A., \& Rickman, D. (2015). Regional economic impacts of the shale gas and tight oil boom: A synthetic control analysis. Regional Science and Urban Economics, 50, 1-17.

NewOn6 (2015). Oklahoma Budget Shortfall Could Be \$900M In 2016. News On 6. http://www.newson6.com/story/30759089/oklahoma-budget-shortfall-couldbe-900m-in-2016, , accessed March 10, 2017.

OCC (2016). Oklahoma Corporation Commission: Chapter 10 - Oil and Gas conservation (OAC 165:10-3-10) in http://www.occeweb.com/rules/rulestxt. htm, accessed January 22, 2016.

OK Policy (2016). Budget Trends and Outlook - 2016. Oklahoma Policy Institute. http://okpolicy.org/budget-trends-and-outlook-january-2016, accessed January 22, 2016.

OK Policy (2017). Budget Trends and Outlook - March 2017. Oklahoma Policy Institute. http://okpolicy.org/budget-trends-outlook-march-2017/, accessed March 10, 2017.

Papke, L. E. (1991). Interstate business tax differentials and new firm location: Evidence from panel data. Journal of Public Economics, 45(1), 47-68. 
Papke, L. E. (1994). Tax policy and urban development: evidence from the Indiana enterprise zone program. Journal of Public Economics, 54(1), 37-49.

Pindyck, R. S. (1978). The Optimal Exploration and Production of Nonrenewable Resources. Journal of Political Economy, 86(5), 841-861.

Plaut, T. R., \& Pluta, J. E. (1983). Business climate, taxes and expenditures, and state industrial growth in the United States. Southern Economic Journal, 99-119.

RRC (2016). Railroad Commission of Texas: Chapter 3 - Oil and Gas Division (TAC 16:1.3) in http://www.rrc.state.tx.us/legal/rules/current-rules/, accessed January 22, 2016.

Schmenner, R. W. (1982). Making business location decisions. Prentice Hall.

Schmenner, R. W., Huber, J. C., \& Cook, R. L. (1987). Geographic differences and the location of new manufacturing facilities. Journal of Urban Economics, 21(1), 83-104.

Strauss-Kahn, V., \& Vives, X. (2009). Why and where do headquarters move? Regional Science and Urban Economics, 39(2), 168-186.

Tannenwald, R. (1996, January). State Business Tax Climate: How Should It Be Measured and How Important Is It? In Proceedings of the Annual Conference on Taxation Held under the Auspices of the National Tax Association-Tax Institute of America (pp. 225-228). National Tax Association-Tax Institute of America.

Tiebout, C. M. (1956). A pure theory of local expenditures. The Journal of Political Economy, 416-424.

Veith, Warren (2014). Drilling Tax Debate Divides Industry Leaders on the Impact of Increase. Tulsa World. (May 21, 2014)

Wasylenko, M. (1999). Taxation and economic development: the state of the economic literature. Public Administration and Public Policy, 72, 309-328.

Weber, Jeremy (2014). A Decade of Natural Gas Development: The Makings of a Resource Curse? Resource and Energy Economics. 37, 168-183.

Weber, Jeremy G. 2012. The Effects of a Natural Gas Boom on Employment and Income in Colorado, Texas, and Wyoming. Energy Economics, 34(5), 15801588.

Weinstein, Amanda L. 2014. Unconventional Oil and Gas Development's Impact on State and Local Economies. Choices, 29(4), 1-7.

Wertz, Joe (2016). In Oklahoma, Low energy Prices Drive State Budget Crisis. NPR. http://www.npr.org/2016/01/19/463622817/in-oklahoma-low-energyprices-drive-state-budget-crisis, accessed March 20, 2017

Wilson, J. D. (1986). A theory of interregional tax competition. Journal of Urban Economics, 19(3), 296-315. 
Wilson, J. D. (1999). Theories of tax competition. National Tax Journal, 269-304.

\section{BIOGRAPHICAL SKETCH OF AUTHORS}

Mary N. Gade is an Associate Professor and Graduate Program Advisor in the Department of Economics and Legal Studies at Oklahoma State University. She received her doctorate in Economics from Michigan State University. Her recent work is focused on state and local tax policy, including property tax incidence, tax increment financing, and oil and gas severance taxes in Oklahoma.

Karen Maguire is an Assistant Professor in the Department of Economics and Legal Studies at Oklahoma State University. She is an active researcher and teacher in the fields of Energy Economics, Environment and Resource Economics, and Regional Economics. Her primary research and teaching focus is on analyzing energy markets, specifically how politics and policies affect energy development.

Francis Makamu is a Visiting Instructor in the Department of Economics and Legal Studies at Oklahoma State University. His research focus is in Development Economics. 


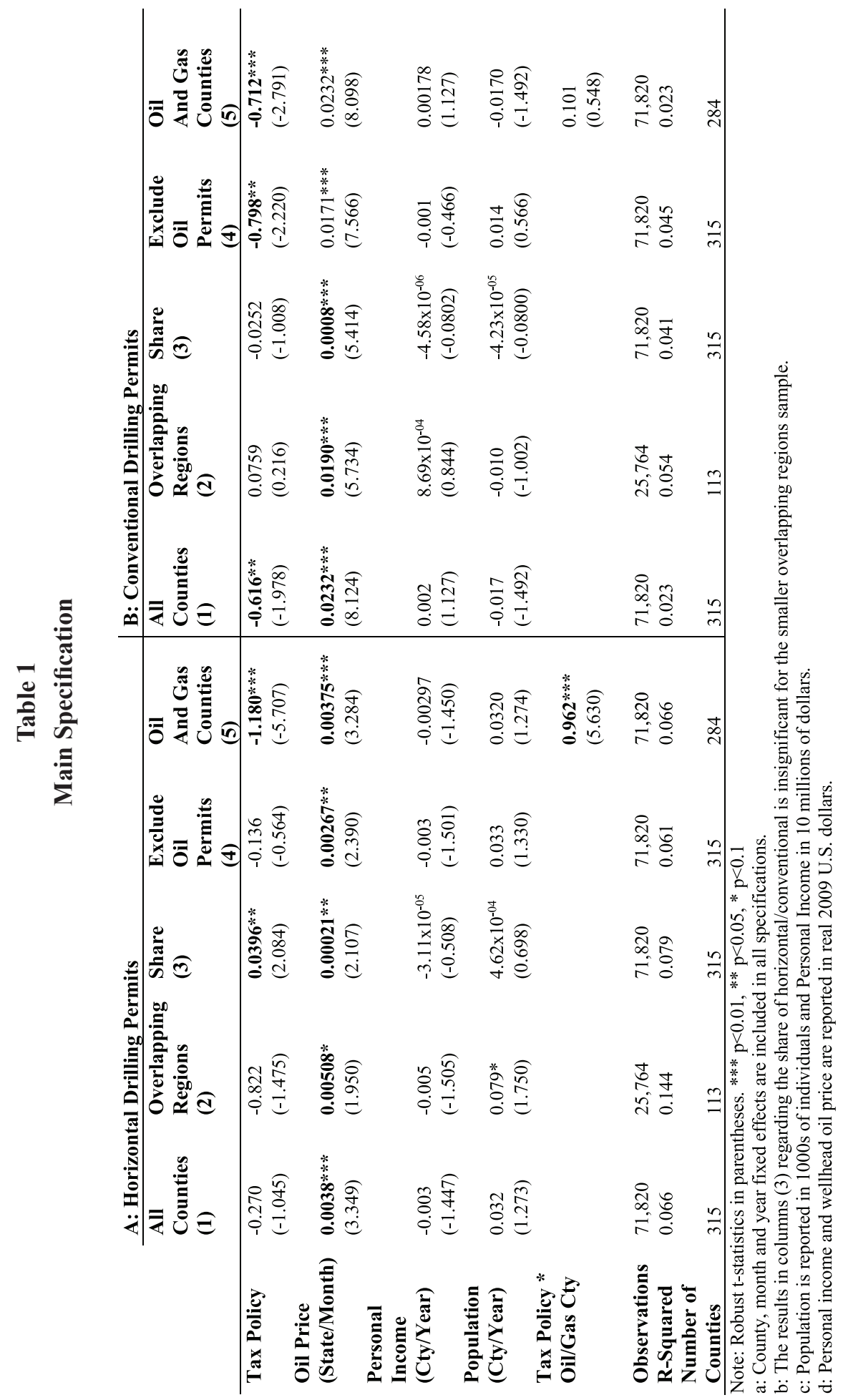


Figure 1

Share of Permits (Horizontal/Conventional) by State

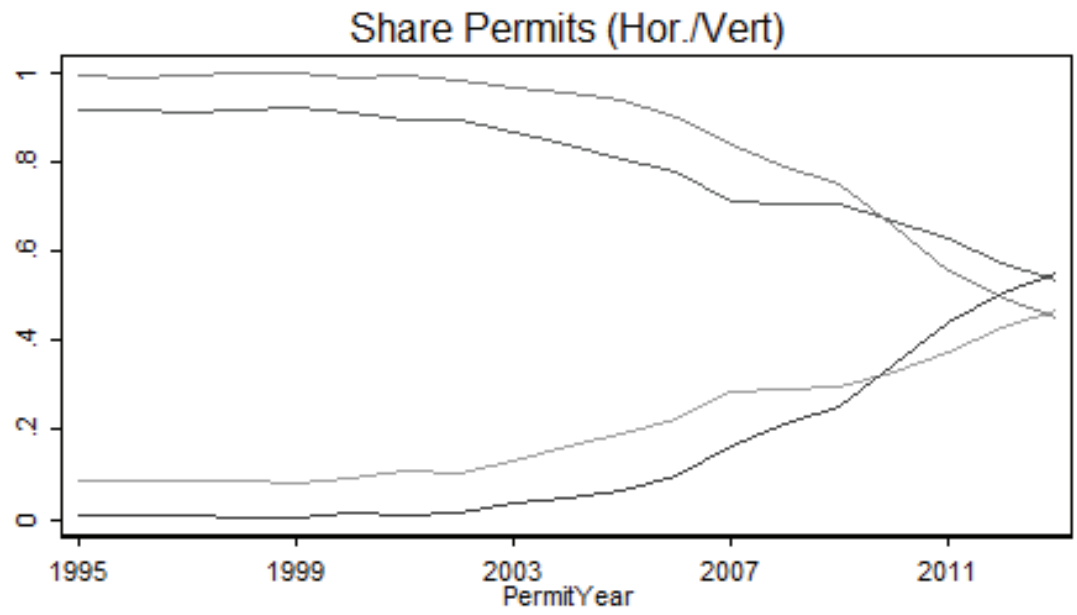

\begin{tabular}{|lr|}
\hline Share TX Conv. Permits & Share TX Horizontal Permits \\
Share OK Conv. Permits & Share OK Horizontal Permits
\end{tabular}

Source: OOGC, Texas RRC

Figure 2

Horizontal and Conventional Permits by State

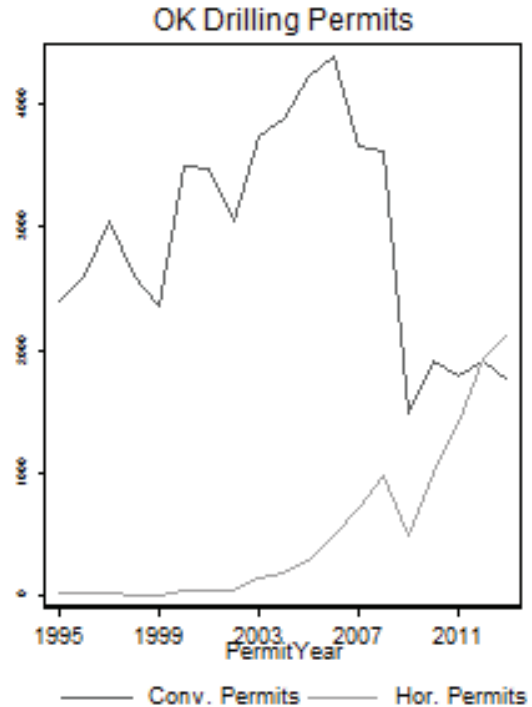

source: 0060

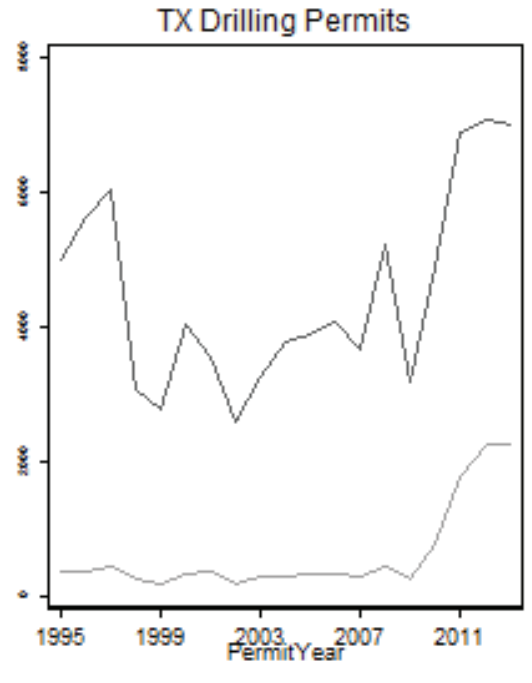

Conv. Permits - Hor. Permits

Bource: $T X$ FaC 
Figure 3

\section{USGS Oil and Gas Provinces for Kansas, Oklahoma, and Texas}

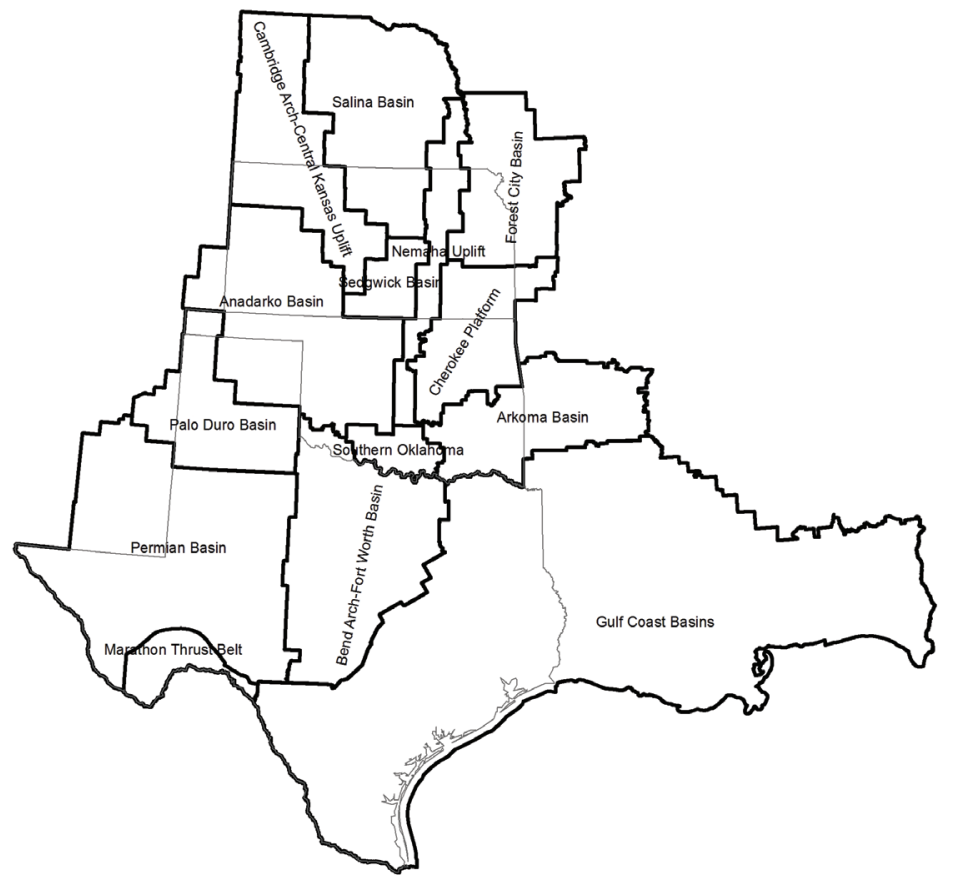

Source: http://energy.usgs.gov/OilGas/AssessmentsData/NationalOilGasAssessment.aspx\#.VW3Pcc-6dpi, http://certmapper.cr.usgs.gov/data/noga00/natl/spatial/geodatabase/usprov12gdb.zip

\section{Figure 4}

\section{Proved Reserves}
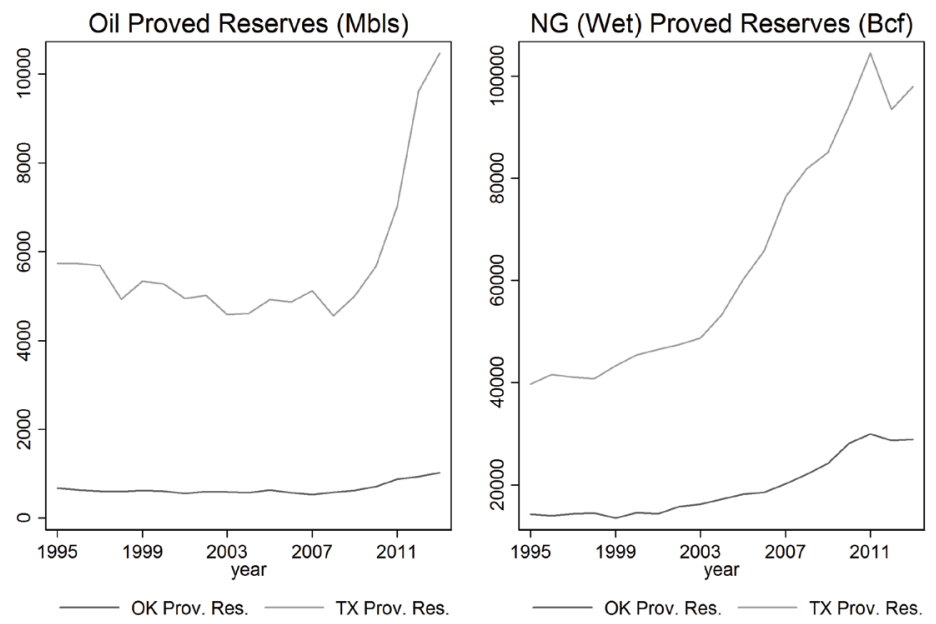


\begin{tabular}{|c|c|c|c|c|c|}
\hline & Sum & $\begin{array}{l}\text { ppendi } \\
\text { mary } S\end{array}$ & $\begin{array}{l}\text { x } 1 \\
\text { atistics }\end{array}$ & & \\
\hline & Mean & Median & $\begin{array}{l}\text { Standard } \\
\text { Deviation }\end{array}$ & Minimum & Maximum \\
\hline $\begin{array}{l}\text { Conventional } \\
\text { Drilling Permits (Cty/Mnth) }\end{array}$ & 3.73 & 1 & 7.18 & 0 & 222 \\
\hline $\begin{array}{l}\text { Horizontal } \\
\text { Drilling Permits (Cty/Mnth) }\end{array}$ & 1.06 & 0 & 4.66 & 0 & 135 \\
\hline $\begin{array}{l}\text { Share Conv. } \\
\text { Permits }\end{array}$ & 0.54 & 0.75 & 0.47 & 0 & 1 \\
\hline $\begin{array}{l}\text { Share Hor. } \\
\text { Permits }\end{array}$ & 0.12 & 0 & 0.28 & 0 & 1 \\
\hline $\begin{array}{l}\text { Conventional } \\
\text { Drilling Permits } \\
\text { - Excl. Oil (Cty/Mnth) }\end{array}$ & 3.46 & 1 & 7.24 & 0 & 149 \\
\hline $\begin{array}{l}\text { Horizontal } \\
\text { Drilling Permits } \\
\text { - Excl. Oil (Cty/Mnth) }\end{array}$ & 0.89 & 0 & 4.29 & 0 & 135 \\
\hline $\begin{array}{l}\text { Population } \\
\text { (Cty/Year) }\end{array}$ & 79046 & 17762 & 289138 & 55 & 4336853 \\
\hline $\begin{array}{l}\text { Real Personal Income } \\
(1000 \text { s \$) }\end{array}$ & 2829139 & 476792 & $1.2 \times 10^{07}$ & 3140 & $2.2 \times 10^{08}$ \\
\hline $\begin{array}{l}\text { Real Wellhead Oil Price } \\
\text { (\$/Barrel) }\end{array}$ & 50.94 & 39.15 & 28.16 & 11.61 & 132.70 \\
\hline
\end{tabular}




\section{Appendix 2}

\section{Summary of Key Policy Changes for Gas Severance Tax Exemptions}

I. Oklahoma Oil and Gas Tax exemptions (OS 68.1001. D, E, F, G, H, I, and J)

Incremental production from enhanced recovery projects, on or after

Horizontally drilled production wells, on or after

2002

Reestablished production from inactive wells, on or after

Production enhancement projects, on or after

Production from deep wells, on or after

Production from new discovery wells, on or after

Production based on three dimensional seismic technology, on or after

2000

\section{Oklahoma Oil and Gas Tax credits}

Oil and gas exemptions are paid when operators file claims for refunds at the end of the fiscal year. The payment can be paid out over a period of 36 months, but in case of late payment the state will be charged a penalty rate of 9 percent interest accrue for each day the required payment is not made.

II. Texas Natural Oil and Gas Tax exemptions (Tax Code title 2 chapter 201.056, 057, 059; 202.056, 060)

High cost gas, on or after

Inactive wells, on or after

Gas that are not taxed are those:

- Injected into earth

- Produced from oil wells and lawfully flared or vented

- Used for lifting oil

\section{Texas Natural Gas Tax credits}

Oil tax credit on inactive wells equal to the difference between the tax paid and the tax which would have been due at the recovered oil tax rate for all production. A low producing gas well is entitled to 25 percent credit if the average price of gas is more than $\$ 3$ per Mcf but less than $\$ 3.50$ per Mcf; a 50 percent credit if the average price of gas is more than $\$ 2.50$ per Mcf but less than $\$ 3$ per Mcf; and 100 percent if the average price of gas is not more than $\$ 2.50$ per Mcf. 